\title{
Logistic regression with machine learning sheds light on the problematic sexual behavior phenotype
}

Shui Jiang ${ }^{1,2}$, Keanna Wallace ${ }^{1,2}$, Esther Yang ${ }^{1,2}$, Leslie Roper ${ }^{1,2}$, Garima Aryal ${ }^{1,2}$, Dawon Lee ${ }^{3}$, Rohit J Lodhi ${ }^{4}$, Rick Isenberg ${ }^{5}$, Bradley Green ${ }^{6}$, David Wishart ${ }^{7}$, Katherine J Aitchison ${ }^{1,2,8^{*}}$

${ }^{1}$ Department of Medical Genetics, University of Alberta, Canada,

${ }^{2}$ Department of Psychiatry, University of Alberta, Canada,

${ }^{3}$ Department of Medicine, University of Alberta, Canada

${ }^{4}$ Department of Psychiatry, University of Western Ontario, Canada,

${ }^{5}$ Psychological Counselling Service, Ltd., Scottsdale, USA,

${ }^{6}$ Department of Psychology and Counseling, University of Texas at Tyler, USA,

${ }^{7}$ Department of Biological Sciences, University of Alberta, Canada,

${ }^{8}$ Neuroscience and Mental Health Institute, University of Alberta, Canada

*Corresponding author:

Email: kaitchis@ualberta.ca (KJA) 


\section{Abstract}

There has been a longstanding debate about whether the mechanisms involved in problematic sexual behavior (PSB) are similar to those observed in addictive disorders, or related to impulse control or compulsivity. The aim of this report was therefore to contribute to this debate by investigating the association between PSB, addictive disorders (internet addiction, compulsive buying), other measures associated with the construct known as reward deficiency (attention deficit disorder and personality disorder), and obsessive-compulsive disorder (OCD) in young adults in post-secondary education.

A Canadian University Office of the Registrar invited 68,846 eligible students and postdoctoral fellows. Out of 4710 expressing interest in participating, 3359 completed on-line questionnaires and 1801 completed the Mini-International Neuropsychiatric Interview (MINI). PSB was measured by combining those screening positive $(\geq 6)$ on the Sexual Addiction Screening Test-Revised (SAST-R) Core with those self-reporting monthly PSB. Current mental health condition(s) and childhood trauma were measured by self-report. OCD was assessed by a combination of self-report and MINI data.

$12.18 \%$ (407/3341) of participants screened positive on the SAST-R Core. On logistic regression analysis (conventional and by machine learning), OCD, attention deficit, internet addiction, a family history of PSB, childhood trauma, compulsive buying and male gender were associated with PSB. On multiple correspondence analysis (MCA), OCD appeared to cluster separately from the other measures, and the pattern of data differed by gender. 
medRxiv preprint doi: https://doi.org/10.1101/2022.01.31.21267382; this version posted February 10, 2022. The copyright holder for this preprint

(which was not certified by peer review) is the author/funder, who has granted medRxiv a license to display the preprint in perpetuity.

All rights reserved. No reuse allowed without permission.

In summary, factors that have previously been associated with the construct known as

RDS and OCD are both associated with increased odds of PSB. The factors associated with RDS appear to contribute to a separate data cluster from OCD, and to lie closer to PSB. 
medRxiv preprint doi: https://doi.org/10.1101/2022.01.31.21267382; this version posted February 10, 2022. The copyright holder for this preprint (which was not certified by peer review) is the author/funder, who has granted medRxiv a license to display the preprint in perpetuity.

All rights reserved. No reuse allowed without permission.

\section{$1 \quad$ 1. Introduction}

2 A theory of hypersexuality with dependence was first proposed by Orford in $1978 .{ }^{1}$ The term sex

3 addiction was used by Carnes in 1983,1990 , and $1991^{2}$ and by Goodman in $1998 .{ }^{3}$ Continuation

4 of a sexual behavior despite adverse consequences and/or distress caused or worsened by the

5 sexual behavior has been a consistent theme in the literature, ${ }^{1,3,4}$ despite differences of opinion as

6 to whether the condition should be classified as an addiction or as an impulse control disorder.

7 Diagnostic criteria proposed by Carnes in $2005^{4}$ led to sex addiction being included in the

8 Diagnostic and Statistical Manual of Mental Disorders (DSM)-III-R (302.87). However, despite

9 draft proposed criteria for the inclusion of sexual addiction and internet addiction in DSM-5, ${ }^{5}$ the

10 only behavioral addiction currently included in DSM-5 (American Psychiatric Association 2013)

11 is gambling disorder (312.31), which was first included in DSM as an impulse control disorder. ${ }^{6}$

12 In the International Statistical Classification of Diseases (ICD), compulsive sexual behavior

13 disorder was proposed for inclusion as an impulse control disorder in $2014,{ }^{7}$ which occurred in

$142018 .{ }^{8}$ However, the scientific discussion about whether or not compulsive sexual behavior

15 disorder could constitute a manifestation of a behavioral addiction was acknowledged, ${ }^{9}$ and it

16 was predicted (as in the case of problematic gambling), ${ }^{6}$ that understanding would evolve as

17 research elucidated the phenomenology and neurobiological underpinnings of the condition.

18 In this article, the term problematic sexual behavior (PSB) is used because it focuses on

19 the behavior rather than on the potentially heterogeneous etiology and pathology. ${ }^{10}$ PSB is

20 characterized by repetitive sexual behaviors and it is associated with uncontrolled sexual

21 urges/impulses and distress, ${ }^{11}$ and social and functional impairments.${ }^{8,11}$ It has been estimated that

22 the prevalence of PSB is 3-6\% in adults, ${ }^{4,12-14}$ with higher frequencies in specific populations,

23 including those in post-secondary education. Reid (2011) reported that $19 \%$ of college men met 
24 criteria for hypersexuality, ${ }^{15}$ while Giordano and Cecil (2014) found $11.1 \%$ of men and women

25 in an undergraduate sample met these criteria. ${ }^{16}$ Cashwell et al. (2015) reported that out of 379

26 undergraduates, $21.2 \%$ of men and $6.7 \%$ of women screened positive, i.e., scored in a range

27 indicating that they should be offered further assessment for sexual addiction. ${ }^{17}$

29 previously associated with the construct known as reward deficiency syndrome (RDS), such as

30 substance ${ }^{18}$ and non-substance use disorders, ${ }^{19} \mathrm{ADHD},{ }^{20}$ personality disorders, ${ }^{21}$ as well as other

31 psychiatric disorders, ${ }^{22}$ and childhood trauma. ${ }^{23}$ In terms of psychiatric disorders, owing to the

32 classification of PSB within ICD-10 as an impulse control disorder, we specifically included

33 obsessive-compulsive disorder. Mick and Hollander (2006) hypothesized that impulsivity

34 initiated the early stage of the PSB, with compulsivity being involved in repetitive behaviors and

35 hence in the maintenance of PSB. ${ }^{24}$ The magnitude of the contribution of the various different

36 postulated mechanisms, and whether PSB encompasses various syndromes with different

37 etiologies is not at present known. Moreover, systematic data on the prevalence of PSB and

38 associated sociodemographic factors across diverse populations, including non-treatment seekers

39 remain to be provided ${ }^{8}$

In light of the above, this paper aims to further elucidate the prevalence,

41 sociodemographic features, phenomenology, and neurobiological underpinnings of the construct

42 known as PSB in a diverse sample of adults in post-secondary education. We hypothesized that

43 in this sample, firstly screening positive for factors previously associated with RDS (such as

44 internet addiction, compulsive buying, nicotine dependence, and pathological gambling) and

45 secondly OCD and childhood trauma would be associated with increased odds of PSB.

\section{Methods}


47 The study inclusion criteria were as follows: at least 18 years of age, undergraduates, graduates, postdoctoral fellows, and recently convocated students registered in at least one course in the

49 preceding year, except for those who had completely withdrawn after registration, without any

50 reasons to not return in the next academic term or not be on campus (such as suspension), and

51 being able to answer in English. A Canadian University Office of the Registrar invited 68,846

52 eligible students and postdoctoral fellows by email. Students interested in participating then

53 emailed the study team. These students were then sent an email invitation to review the

54 participant information and complete consent on-line, followed by the screening measures

55 (hosted by the Qualtrics platform), with a subsequent email inviting them to complete the Mini-

56 International Neuropsychiatric Interview (MINI).

\subsection{Measures}

58 The Sexual Addiction Screening Test-Revised (SAST-R) ${ }^{25}$ is a 45-item screening tool comprising several subscales designed to detect potentially problematic sexual behavior. Each

60 question is answered in a binary manner (yes/no=0/1). Sexual activities deemed to be

61 problematic by participants in the past 30 days were also separately assessed by asking the

62 following question: "Within the last 30 days, how often have you participated in activities of a 63 sexual nature that you would regard as problematic?”

Measures used to screen for internet addiction, compulsive buying, personality disorders,

65 ADHD, nicotine dependence, and pathological gambling were the Internet Addiction Test

66 (IAT), ${ }^{26}$ the Richmond Compulsive Buying Scale (RCBS),${ }^{27}$ the 8 -item SA-SAPAS,${ }^{28}$ the full

67 Adult ADHD Self-Report Scale (ASRS-v1.1), ${ }^{29}$ the Fagerström Test for Nicotine Dependence

68 (FTND) $)^{30}$ and the DSM-V Pathological Gambling Diagnostic Form (PGDF), ${ }^{31}$ respectively. The

69 self-report online administered Mini-International Neuropsychiatric Interview (MINI) version 
7.0.2 was used to output psychiatric disorders by DSM-5 criteria. Having received a diagnosis of

71 OCD, any other mental health condition(s), childhood physical, emotional/verbal, or sexual

72 trauma, and a family history of domestic violence or of sexual addiction, gender and sexual

73 orientation were additionally collected by self-report.

\subsubsection{Demographic data and logistic regression}

76 Data were analyzed by STATA (Stata/SE 16) and R (Version 3.6.3) after dropping all of the

77 missing data.

A “total PSB” variable was created by combining those screening positive on the SAST-

79 R Core with those endorsing monthly self-reported PSB. Previous or current physical/emotional/sexual childhood trauma and a family history of domestic violence (11.77\%

$81387 / 3288$ ) were regrouped as total childhood trauma due to the relatively low rates of

82 endorsement for the former group (physical trauma: 2.98\%, 99/3322; emotional trauma: 6.87\%,

83 232/3322; sexual trauma: 3.31\%, 110/3212). SAST Core question 1 (which enquires about a

84 history of sexual abuse in childhood or adolescence, SASTC1) was combined with total

85 childhood trauma. The self-reported family history of sexual addiction ("yes"/ "no") data was

86 combined with SAST Core question 2 (which enquires about parental trouble with sexual

87 behaviour, SASTC2) to create a new family history of PSB variable. IAT was regrouped as

88 "yes" $(\mathrm{N}=1174$, combining mild, moderate, and severe groups) and "no" (N=2160, the "normal"

89 group). Owing to much lower endorsement rates (or lower than in another university student

90 sample $),{ }^{32}$ the FTND $(0.45 \%, 15 / 3332)$ and PGDF $(2.28 \%, 76 / 3332)$ scores were dropped. In

91 addition, due to the small numbers in the gender and sexual orientation minority subgroups, only

92 men and women were included in the logistic regression analysis $(\mathrm{N}=3091)$. 
Two-sample Wilcoxon rank-sum tests were used to determine the age difference between

94 the PSB- positive and -negative groups. Data distributions were assessed by Pearson $\chi^{2}$ test.

95 Tetrachoric (for binary variables) and Kendall's $\tau$ (for categorical variables) correlations were

96 utilized. SA-SAPAS, OCD, ASRS, IAT, childhood trauma, a family history of PSB and gender

97 were used as covariates in regression analyses (Figure 2, Table 2-4). All reported $P$ values are

98 nominal. Multiple correspondence analysis (MCA) was used for data clustering.

\subsubsection{Machine learning approaches}

100 The "Haven" and "dplyr" packages were used for data input. The "forcats" and "creditmodel"

101 packages were used for recoding and splitting (80\% training $20 \%$ testing), respectively. The

102 Synthetic Minority Oversampling Technique (SMOTE) from the "Caret" package was used to

103 address data imbalance in the training set. ${ }^{33}$ The leave-one-out cross-validation (LOOCV) in the

104 "Caret" package was used for resampling. ${ }^{34}$ Logistic regression (two-class summary) in the

105 "caret" package was used for regression. Accuracy, area under the receiver operating

106 characteristic (ROC) curve, sensitivity, specificity, and F score were used to evaluate the models.

107 The "pROC" package was used for the area under the ROC curve.

\subsubsection{Multiple correspondence analysis (MCA)}

109 Multiple correspondence analysis was conducted on OCD, RCBS, SA-SAPAS, ASRS, IAT, and

110 childhood trauma stratifying by gender (women $\mathrm{N}=2084$ and men $\mathrm{N}=1012$ ). As a family history

111 of PSB was correlated with the combined childhood trauma variable (tetrachoric $\varrho=0.69$,

$112 P<0.001, \mathrm{~N}=3019$, Figure 1, Supplementary Table 3), these variables were combined as a quality

113 supplementary childhood trauma-related variable. The "FactoMineR," "factoextra," and

114 "GDAtools" packages in R were used for analysis and data visualization.

$115 \quad 3$. Results 
medRxiv preprint doi: https://doi.org/10.1101/2022.01.31.21267382; this version posted February 10,2022 . The copyright holder for this preprint (which was not certified by peer review) is the author/funder, who has granted medRxiv a license to display the preprint in perpetuity.

All rights reserved. No reuse allowed without permission.

116 Out of 4710 interested in participating, 237 withdrew from the study, 3359 completed online

117 questionnaires using the Qualtrics platform, and 1801 completed the MINI (Supplementary

118 Figure 1).

\subsection{Demographic data}

120 The mean score on the SAST-R Core Scale among all participants was $2.23(\mathrm{SD}=2.73)$, with

$121 \quad 12.18 \%(407 / 3341)$ of participants scoring at least six (the threshold for screening positive in the

122 general population. ${ }^{25}$ Of the 20 items composing the SAST-R Core questions, item 11 (Do you

123 hide some of your sexual behavior from others?) was the most endorsed (1234/3341,

124 endorsement rate: $36.78 \%$ ), while item 9 (“Are any of your sexual activities against law?”) was

125 the least endorsed (35/3342; endorsement rate: 1.05\%) (Supplementary Table 1). The frequency

126 of participants included in the total PSB variable was $16.53 \%(532 / 3219)$. There was a

127 significant difference in the distribution of the following variables by those with and without

128 PSB: gender, sexual orientation, OCD, RCBS, a family history of PSB, SA-SAPAS, current

129 mental health condition(s), childhood trauma, ASRS, and IAT (Table 1 and Supplementary

130 Table 2).

131 Data correlation showed that PSB was correlated with non-heterosexual sexual

132 orientation (baseline: heterosexual), current mental health condition(s), childhood trauma,

133 RCBS, OCD, SA-SAPAS, a family history of PSB, ASRS, IAT and gender (baseline: women)

134 (Figure 1, Supplementary Table 3). Multiple variables were correlated with one another. For

135 example, sexual orientation was correlated with current mental health condition(s). Current

136 mental health condition(s) were correlated with childhood trauma, OCD, SA-SAPAS, ASRS;

137 and were negatively correlated with gender (baseline: women). RCBS was negatively correlated

138 with gender (baseline: women). In addition, our results indicated that that after subtracting 
SASTC1 and SASTC2, the PSB variable still had a strong correlation with SAST-R Core; and SAST-R Core was correlated with self-reported PSB (Supplementary Table 4). Similarly, self-

141 reported OCD was correlated with MINI-identified OCD (Supplementary Table 4).

\subsection{Regression models}

\subsubsection{Logistic regression}

144 Outliers were removed from logistic regression $(\mathrm{N}=47$, with 8 responding "yes" to total PSB,

145 Supplementary Figure 2) if their Pearson standardized residual had an absolute value of more

146 than $2,{ }^{35}$ or Hosmer-Lemeshow $\Delta \widehat{\beta}$ more than four ${ }^{36}$ After outlier removal as above, no further

147 outliers needed to be removed on the basis of leverage values (a measure of the distance between

148 independent variable observations). The following variables were associated with PSB (pseudo

$\left.149 R^{2}=0.16\right)$ : OCD $(P=0.015)$, ASRS $(P<0.001)$, IAT $(P<0.001)$, a family history of PSB $(P<0.001)$,

150 SA-SAPAS $(P<0.001)$, childhood trauma $(P<0.001)$, RCBS $(P<0.001)$ and gender $(m e n)$

$151(P<0.001)$ (Figure 2, Table 2).

\subsubsection{Machine Learning (ML) logistic regression}

153 Our ML logistic regression showed that RCBS $(P=0.0030)$, SA-SAPAS $(P<0.001)$, OCD

$154(P<0.001)$, a family history of PSB $(P<0.001)$, ASRS $(P<0.001)$, childhood trauma $(P<0.001)$,

155 IAT $(P<0.001)$, and gender $($ men $)(P<0.001)$ were all associated with increased odds of PSB

156 (Figure 2B, Table 4). A validation of the existing model was also undertaken (Figure 2C, Table

157 3). The validation model was trained with SAST-R Core (subtracting SASTC1 and SASTC2,

$158 \mathrm{~N}=3141)$ and tested with self-reported PSB (N=3145). 
160 The MCA results showed that in both women and men, the first two dimensions accounted for

161 the most explained variance (Supplementary Figure 5). PSB had a high degree of representation

162 in all dimensions (Supplementary Table 7). PSB was strongly represented in both men and

163 women in dimensions 1,2,4 and 5, although showing slightly different data clustering patterns

164 by gender in these dimensions (Figure 3-4). In dimension 1 (44.00\% of the explained variance in

165 women and 39.10\% of the explained variance in men, Figure 3 and Supplementary Figure 5),

166 PSB was correlated with all variables in women and men. In dimension 2 (15.00\% of the

167 explained variance in women and $17.30 \%$ of the explained variance in men, Figure 3 and

168 Supplementary Figure 5), PSB clustered with IAT and ASRS in men, and with RCBS, IAT and

169 ASRS in women. In women, in dimension 4 (10.50\% of the explained variance) and dimension 5

170 (10.10\% of the explained variance), PSB was correlated with childhood trauma-related variables.

171 In men, by contrast, PSB was correlated with childhood trauma-related variables just in

172 dimension 5 (10.50\% of the explained variance) but not in dimension 4 (11.60\% of the explained

173 variance) (Figure 4, Supplementary Figure 5). The contributions of variables to each dimension

174 by gender is shown in Supplementary Figures 6-7 and Supplementary Table 8.

\section{Discussion}

176 The frequency of problematic sexual behavior, as defined by screening positive on the SAST-R

177 Core, was $8.49 \%$ in the women and $19.70 \%$ in the men in this post-secondary education sample,

178 consistent with prior reports in this population. ${ }^{15-17}$

Factors consistently associated with increased odds of PSB were gender, mental health

180 conditions (ADHD, personality disorder, and OCD), other problematic behaviors such as internet

181 addiction (IAT) and compulsive buying (RCBS), childhood trauma (including a family history of

182 domestic violence), and a family history of PSB. Our results also showed that self-reported data 
183 were correlated with the screening tool or MINI data. For example, the binary SAST-R core was

184 significantly correlated with self-reported "problematic sexual activities in the past 30 days"

$185\left(\tau_{\mathrm{b}}=0.44, P<0.001, \mathrm{~N}=2049\right)$ and "maximum length of time on any single occasion spent in

186 problematic sexual activities" $\left(\tau_{\mathrm{b}}=0.32, P<0.001, \mathrm{~N}=2049\right)$. IAT is significantly associated with

187 self-reported "problematic internet use in the past 30 days" (four categories IAT: $\tau_{\mathrm{b}}=0.42, P<$

1880.001 ; binary IAT: $\left.\tau_{\mathrm{b}}=0.40, P<0.001, \mathrm{~N}=1441\right)$. SA-SAPAS was significantly correlated with

189 antisocial personality order diagnosed by MINI (tetrachoric $\varrho=0.24, P=0.026, \mathrm{~N}=1788$ ) and with

190 self-reported borderline personality disorder (tetrachoric $\mathrm{Q}=0.44, P<0.001, \mathrm{~N}=1429$ ).

191 Interestingly, a family history of PSB was shown to be strongly correlated with childhood trauma

192 in our dataset (tetrachoric $\varrho=0.69, P<0.001, \mathrm{~N}=3019$, Figure 1, Supplementary Table 3), and

193 both were associated with PSB. Of those responding "yes" to a family history of sexual

194 addiction, $32.65 \%$ (16/49) screened positive on the SAST-R Core. The combined variable,

195 including a family history of sexual addiction and SASTC2 (with 6.55\% endorsement: 214/3268)

196 was significant in all models.

197 Our model validation did show a lower F score than the final model training and testing

198 with total PSB, probably due to the difference between screening and self-report data (training

199 with SAST-R Core and testing with self-reported PSB, Figure 2C, Table 4). A sensitivity

200 analysis (Supplementary Figure 3-4, Supplementary Table 5-6) was undertaken using the

201 original variables, namely SAST-R Core (without subtracting SASTC1 and SASTC2), childhood

202 trauma (without adding SASTC1 or a family history of domestic violence) and a family history

203 of sexual addiction (without incorporating SASTC2). The logistic regression model using these

204 variables (pseudo $\left.R^{2}=0.13\right)$ revealed that RCBS $(P=0.033)$, ASRS $(P<0.001)$, IAT $(P<0.001)$,

205 OCD $(P<0.001)$, childhood trauma $(P<0.001)$, and gender (baseline: women, $P<0.001)$ remained 
significant, but not a family history of sexual addiction $(P=0.17)$, probably due to the lower

207 frequency of endorsement of this variable $(\mathrm{N}=49)$ compared to SASTC2. Using the new total

208 PSB variable, childhood trauma, a family history of PSB and excluding sexual orientation as

209 well as current mental health condition(s) improved the sensitivity and F-score in logistic

210 regression. This strategy also improved the specificity and F score in ML logistic regression. ML

211 logistic regression in general showed a higher sensitivity and F score compared to logistic

212 regression.

213 The variables previously associated with the RDS construct, such as SA-SAPAS, ASRS,

214 and IAT, were associated with increased odds of PSB. In the final logistic (Figure 2, Table 2)

215 and ML logistic regression (Figure 2, Table 3), RCBS was associated with increased odds of

216 PSB. Of note, there were gender differences regarding RCBS: RCBS was negatively correlated

217 with men (Figure 1, baseline: women), and PSB displayed a weaker association with RCBS in

218 men on MCA (Figures 3 and 4).

In addition, interestingly, the distribution of PSB differed significantly between OCD-

220 positive and -negative groups $(P<0.001$, Table 2$)$, and PSB was correlated with OCD $(r=0.27$,

$221 P<0.001$, Figure 1, Supplementary Table 3). In our final regression models and sensitivity

222 analyses (by both logistic and ML logistic regression), OCD was associated with increased odds

223 of PSB (OR 1.79, $P=0.015$; and OR 1.85, $P=0.013$, Sensitivity model: OR 2.28, $P<0.001$; and

224 OR 1.73, $P=0.033$, respectively). The MCA results also indicated that PSB had a less strong

225 association with OCD than with SA-SAPAS, IAT and ASRS in women and men, as it clustered

226 further away from PSB (Figure 3).

227 Limitations of this study include the following. Firstly, as respondents to the email from

228 the registrar knew the subject area of the study, there is a potential selection bias. However, the 
frequency of PSB in our dataset was comparable to that seen in other studies of adults in postsecondary education as mentioned above..$^{12,17}$ Subsample sizes were a limiting factor in sexual

231 orientation and in gender subgroups other than cis-men and cis-women, and therefore the smaller

232 groups were combined or dropped. Another potential limitation is that we dropped missing

233 values (rather than using imputation). Various methods may be used to deal with missing data.

234 Some such methods (e.g., multiple by monotone imputation, or imputation by chained equations)

235 may introduce bias, and perfect (inaccurate) predictions, as the methods themselves involve the

236 fitting of a regression model for a categorical outcome. ${ }^{37}$ However, if the proportion of missing

237 data is relatively small (5\% or less), this should not be problematic..$^{38}$ In our sample, the feature

238 with the most missing data in the SAST-R core scale was: "SASTC14 -- Feel depressed after

239 having sex, "with only 16 out of $3341(0.48 \%)$ missingness (and out of those 16 participants,

240 only 1 scored as SAST-R core positive). Another limitation is that logistic regression is sensitive

241 to high correlations among predictor variables. Although several variables were correlated with

242 each other in our dataset, correlation coefficients among these variables were less than $0.80,{ }^{39}$

243 and the mean variance inflation factor (VIF) and the condition number were at acceptable levels

$244(\mathrm{VIF}<10$, condition number $<10)$ for our final models,${ }^{40}$ indicating multicollinearity was not a

245 significant concern. A power calculation is provided in Supplementary Table 9. Using our model 246 parameters, a sample size of 361 would have a power of 0.90.

248 that is as yet unexplained by our models (pseudo $R^{2}=0.16$, Table 2 ). Future directions should

249 include incorporating such factors, and optimizing the model for enhanced predictive power

250 through the comparison and use of alternative machine learning models, feature selection 
251 techniques, and methods for computing missing values, as well as expanding the validation by

252 the use of additional independent datasets.

\section{Conclusions}

254 In summary, we have identified associations between problematic sexual behavior in adults in

255 post-secondary education participating in a study on this topic and the following: compulsive

256 buying, personality disorder, OCD, ADHD, childhood trauma, a family history of PSB, internet

257 addiction, and gender (men). Our results not only suggest that measures associated with reward

258 deficiency syndrome are associated with PSB, but also that OCD is a vulnerability factor with a

259 separate contribution. Childhood trauma and a family history of domestic violence also showed

260 associations with PSB, implying that emotional regulation and attachment style may be involved

261 in the development of PSB. Our data are consistent with different subgroups within PSB with

262 contrasting etiological mechanisms that differ by gender.

\section{6. Acknowledgments}

264 We would like to acknowledge the contribution of Dr. Patrick Carnes to the study design, and

265 volunteer input of Penny Carnes, Grace Li, Hana Graham, and Chanelle Martens to data

266 collection. SJ would like to thank Afia Anjum from DW's lab for her assistance with R.

\section{Funding}

268 The study was funded by an Alberta Centennial Addiction and Mental Health Research Chair

269 and translational funding (to KJA), and by the American Foundation for Addiction Research.

270 Several scholarships, including the University of Alberta Dean's Doctoral Student Award 2021-

2712022 (to SJ), University of Alberta Medical Science Graduate Program Scholarship 2020 (to SJ),

272 University of Alberta Doctoral Recruitment Scholarship 2017 (to SJ), Alberta Graduate 
medRxiv preprint doi: https://doi.org/10.1101/2022.01.31.21267382; this version posted February 10, 2022. The copyright holder for this preprint

(which was not certified by peer review) is the author/funder, who has granted medRxiv a license to display the preprint in perpetuity.

All rights reserved. No reuse allowed without permission.

273 Excellence Scholarship 2020 (to SJ), and a Janssen Inc., Canada Fellowship (fellowship to KJA;

274 fellow=SJ) provided additional funding for the first author. A Fulbright-Canada-Palix

275 Foundation grant to Dr. Patrick Carnes facilitated his contributions to study design. 
Table 1. Distribution of demographic and clinical variables by total PSB group

\begin{tabular}{|c|c|c|c|}
\hline Categories & $\begin{array}{c}\text { Total PSB responding "yes" } \\
532 / 3219(16.53 \%)\end{array}$ & $\begin{array}{l}\text { Total PSB responding “no” } \\
2687 / 3219(83.47 \%)\end{array}$ & $\begin{array}{l}\text { Total } \\
\text { number }\end{array}$ \\
\hline SAST scores & $6.58 \pm 3.22(\mathrm{~N}=532)$ & $1.38 \pm 1.56(\mathrm{~N}=2687)$ & 3219 \\
\hline \multicolumn{4}{|c|}{ Two-sample Wilcoxon rank-sum (Mann-Whitney) test, $P<0.001$} \\
\hline Age & $22.32 \pm 5.13(\mathrm{~N}=532)$ & $22.34 \pm 5.05(\mathrm{~N}=2686)$ & 3218 \\
\hline \multicolumn{4}{|c|}{ Two-sample Wilcoxon rank-sum (Mann-Whitney) test, $P=0.81$} \\
\hline \multicolumn{4}{|c|}{ Gender } \\
\hline $\begin{array}{c}\text { Women } \\
(\mathrm{N}=2145)\end{array}$ & $232(10.82 \%)$ & $1913(89.18 \%)$ & 2145 \\
\hline $\begin{array}{c}\text { Men } \\
(\mathrm{N}=1026)\end{array}$ & $290(28.27 \%)$ & $736(71.73 \%)$ & 1026 \\
\hline \multicolumn{4}{|c|}{ Pearson $\chi^{2}(2)=153.66, P<0.001$} \\
\hline \multicolumn{4}{|c|}{ Sexual Orientation } \\
\hline $\begin{array}{l}\text { Heterosexual } \\
\qquad(\mathrm{N}=2650)\end{array}$ & $420(15.85 \%)$ & $2230(84.15 \%)$ & 2650 \\
\hline $\begin{array}{c}\text { Non-heterosexual } \\
(\mathrm{N}=564)\end{array}$ & $110(19.50 \%)$ & $454(80.50 \%)$ & 564 \\
\hline \multicolumn{4}{|c|}{ Pearson $\chi^{2}(1)=4.51, P=0.034$} \\
\hline
\end{tabular}




\begin{tabular}{|c|c|c|c|}
\hline \multicolumn{4}{|c|}{ OCD (self-reported current diagnosis and MINI) } \\
\hline No & $490(15.88 \%)$ & $2596(84.12 \%)$ & 3086 \\
\hline Yes & $40(33.33 \%)$ & $80(66.67 \%)$ & 120 \\
\hline Total & $530(16.53 \%)$ & $2676(83.47 \%)$ & 3206 \\
\hline \multicolumn{4}{|c|}{ Pearson $\chi^{2}(1)=25.51, P<0.001$} \\
\hline \multicolumn{4}{|c|}{ RCBS } \\
\hline No & $471(15.54 \%)$ & $2559(84.46 \%)$ & 3030 \\
\hline Yes & $61(32.28 \%)$ & $128(67.72 \%)$ & 189 \\
\hline Total & $532(16.53 \%)$ & $2687(83.47 \%)$ & 3219 \\
\hline \multicolumn{4}{|c|}{ Pearson $\chi^{2}(1)=36.10, P<0.001$} \\
\hline \multicolumn{4}{|c|}{ A family history of PSB (a family history of sexual addiction with SASTC2) } \\
\hline No & $453(15.38 \%)$ & $2492(84.62 \%)$ & 2945 \\
\hline Yes & $71(34.63 \%)$ & $134(65.37 \%)$ & 205 \\
\hline Total & $524(16.63 \%)$ & $2626(83.37 \%)$ & 3150 \\
\hline \multicolumn{4}{|c|}{ Pearson $\chi^{2}(1)=51.22, P<0.001$} \\
\hline \multicolumn{4}{|c|}{ SA-SAPAS } \\
\hline No & $425(14.76 \%)$ & $2454(85.24 \%)$ & 2879 \\
\hline Yes & $107(31.47 \%)$ & $233(68.53 \%)$ & 340 \\
\hline Total & $532(16.53 \%)$ & $2687(83.47 \%)$ & 3219 \\
\hline \multicolumn{4}{|c|}{ Pearson $\chi^{2}(1)=61.54, P<0.001$} \\
\hline \multicolumn{4}{|c|}{ Current mental health condition(s) } \\
\hline No & $399(15.35 \%)$ & $2200(84.65 \%)$ & 2599 \\
\hline
\end{tabular}




\begin{tabular}{|c|c|c|c|}
\hline Yes & $131(21.87 \%)$ & $468(78.13 \%)$ & 599 \\
\hline Total & $530(16.57 \%)$ & $2668(83.43 \%)$ & 3198 \\
\hline \multicolumn{4}{|c|}{ Pearson $\chi^{2}(1)=14.96, P<0.001$} \\
\hline \multicolumn{4}{|c|}{$\begin{array}{l}\text { Childhood trauma (physical, verbal/emotional, sexual childhood trauma with SASTC1 } \\
\text { and a family history of domestic violence) }\end{array}$} \\
\hline No & $339(13.94 \%)$ & $2092(86.06 \%)$ & 2431 \\
\hline Yes & $185(25.45 \%)$ & $542(74.55 \%)$ & 727 \\
\hline Total & $524(16.59 \%)$ & $2634(83.41 \%)$ & 3158 \\
\hline \multicolumn{4}{|c|}{ Pearson $\chi^{2}(1)=53.50, P<0.001$} \\
\hline \multicolumn{4}{|c|}{ ASRS } \\
\hline No & $321(12.97 \%)$ & $2153(87.03 \%)$ & 2474 \\
\hline Yes & $211(28.32 \%)$ & $534(71.68 \%)$ & 745 \\
\hline Total & $532(16.53 \% \%)$ & $2687(83.47 \%)$ & 3219 \\
\hline \multicolumn{4}{|c|}{ Pearson $\chi^{2}(1)=97.76, P<0.001$} \\
\hline \multicolumn{4}{|c|}{ IAT } \\
\hline Normal (No) & $241(11.50 \%)$ & $1855(88.50 \%)$ & 2096 \\
\hline $\begin{array}{l}\text { Mild, moderate } \\
\text { and severe (Yes) }\end{array}$ & $291(25.91 \%)$ & $832(74.09 \%)$ & 1123 \\
\hline Total & $532(16.53 \%)$ & $2687(83.47 \%)$ & 3219 \\
\hline \multicolumn{4}{|c|}{ Pearson $\chi^{2}(3)=110.13, P<0.001$} \\
\hline
\end{tabular}


Table 2. Results of logistic regression analysis of total PSB (N=3049, after removing outliers)

\begin{tabular}{|c|c|}
\hline Log likelihood $=-1149.98$ & $\begin{array}{c}\text { Number of observations }=3049, \\
\qquad P<0.00001, \\
\text { pseudo } \mathrm{R}^{2}=0.16\end{array}$ \\
\hline Variable & Odds Ratio, $95 \%$ CI \\
\hline $\begin{array}{l}\text { OCD (self-reported current diagnosis } \\
\text { with MINI data, baseline: no) }\end{array}$ & $1.79, \mathrm{CI}: 1.12-2.86, P=0.015$ \\
\hline ASRS (bassline: no) & 1.93, CI: $1.54-2.42, P<0.001$ \\
\hline IAT (baseline: normal) & $2.00, \mathrm{CI}: 1.61-2.49, P<0.001$ \\
\hline $\begin{array}{l}\text { A family history of PSB (a family } \\
\text { history of sexual addiction with } \\
\text { SASTC2, baseline: no) }\end{array}$ & $2.05, \mathrm{CI}: 1.38-3.05, P<0.001$ \\
\hline SA-SAPAS (baseline: no) & 2.14, CI: $1.59-2.86, P<0.001$ \\
\hline $\begin{array}{l}\text { Childhood trauma (physical, } \\
\text { verbal/emotional and sexual childhood } \\
\text { trauma, SASTC1, with a family history } \\
\text { of domestic violence, baseline: no) }\end{array}$ & 2.18, CI: $1.69-2.79, P<0.001$ \\
\hline RCBS (baseline: no) & $2.53, \mathrm{CI}: 1.74-3.68, P<0.001$ \\
\hline Gender (baseline: women) & $4.40, \mathrm{CI}: 3.53-5.49, P<0.001$ \\
\hline Model Accuracy & $84.32 \%$ \\
\hline Area under the ROC curve & $77.37 \%$ \\
\hline
\end{tabular}


medRxiv preprint doi: https://doi.org/10.1101/2022.01.31.21267382; this version posted February 10, 2022. The copyright holder for this preprint (which was not certified by peer review) is the author/funder, who has granted medRxiv a license to display the preprint in perpetuity.

All rights reserved. No reuse allowed without permission.

\begin{tabular}{|c|c|}
\hline Sensitivity & $14.46 \%$ \\
\hline Specificity & $98.19 \%$ \\
\hline F-score (harmonic mean of Precision \\
and Recall) & 0.23 \\
\hline
\end{tabular}

The model passed the linktest with a significant $P($ hat $)(P<0.001)$ and a non-significant $P($ hatsq $)$

$(P=0.12)$. The probability of the Hosmer-Lemeshow $\chi^{2}$ test was insignificant $(P=0.64)$,

suggesting a good model fit. The mean variance inflation factor (VIF) and the condition number were 1.08 and 3.26 , respectively. 
Table 3. Results of machine learning (ML) logistic regression of total PSB

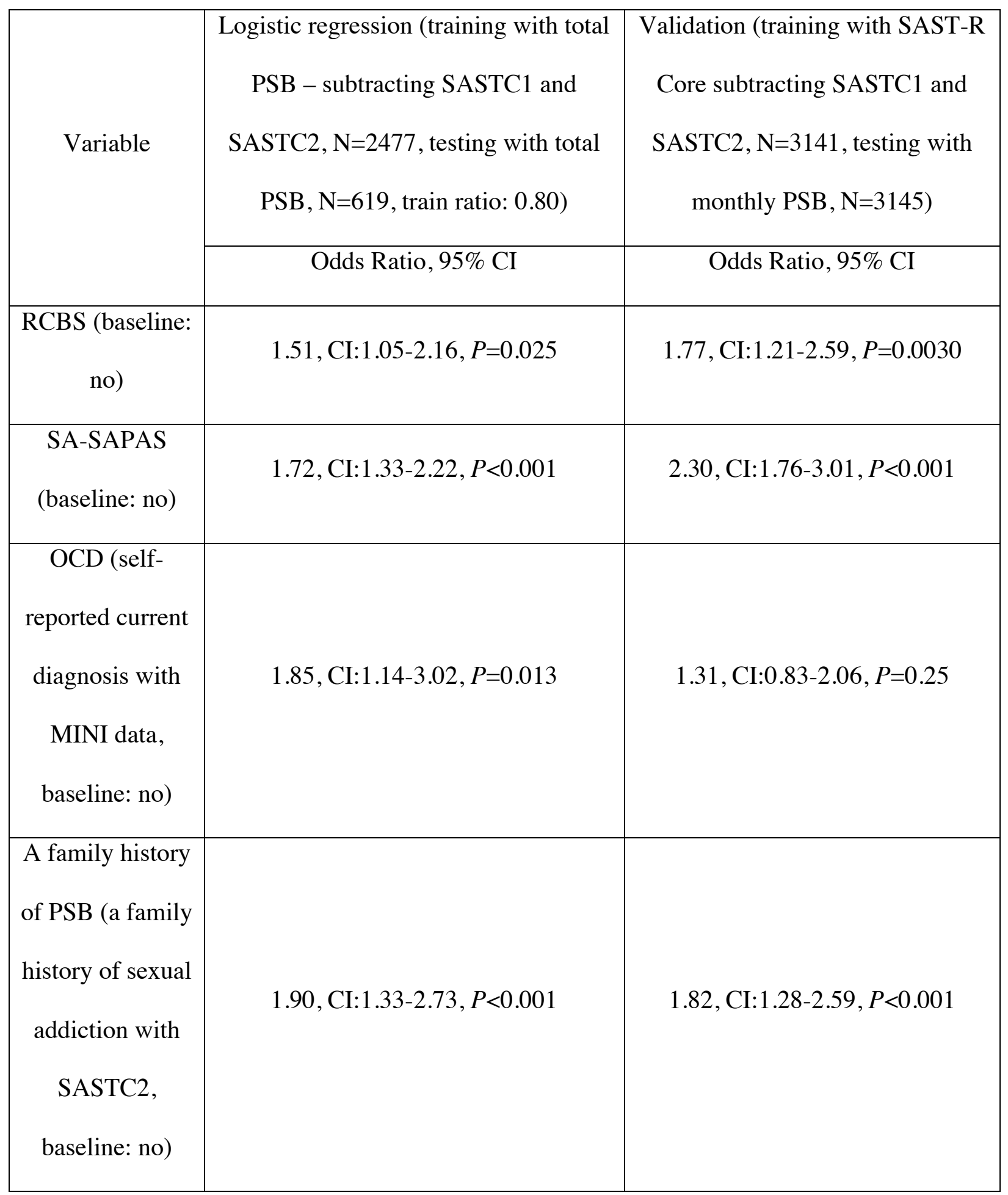




\begin{tabular}{|c|c|c|}
\hline $\begin{array}{c}\text { ASRS (bassline: } \\
\text { no) }\end{array}$ & 1.99, CI:1.64-2.41, $P<0.001$ & 1.89, CI:1.53-2.32, $P<0.001$ \\
\hline $\begin{array}{c}\text { Childhood } \\
\text { trauma } \\
\text { (physical, } \\
\text { verbal/emotional } \\
\text { and sexual } \\
\text { childhood } \\
\text { trauma, } \\
\text { SASTC1, with a } \\
\text { family history of } \\
\text { domestic } \\
\text { violence, }\end{array}$ & 2.23 CI:1.81-2.75, $P<0.001$ & 2.30, CI: $1.84-2.87, P<0.001$ \\
\hline $\begin{array}{l}\text { IAT (baseline: } \\
\text { normal) }\end{array}$ & 2.37, CI:1.97-2.84, $P<0.001$ & $2.11, \mathrm{CI}: 1.74-2.55, P<0.001$ \\
\hline $\begin{array}{l}\text { Gender } \\
\text { (baseline: } \\
\text { women) }\end{array}$ & 4.80, CI:4.01-5.76, $P<0.001$ & 3.83, CI:3.16-4.65, $P<0.001$ \\
\hline $\begin{array}{c}\text { Training } \\
\text { performance }\end{array}$ & $\begin{array}{c}\text { Training ROC }=75.72 \% \\
\text { Sensitivity }=79.70 \% \\
\text { Specificity }=58.02 \%\end{array}$ & $\begin{array}{c}\text { Training } \mathrm{ROC}=76.16 \%, \\
\text { Sensitivity }=78.31 \% \\
\text { Specificity }=62.28 \%\end{array}$ \\
\hline Model Accuracy & $74.64 \%$ & $75.04 \%$ \\
\hline
\end{tabular}


medRxiv preprint doi: https://doi.org/10.1101/2022.01.31.21267382; this version posted February 10,2022 . The copyright holder for this preprint (which was not certified by peer review) is the author/funder, who has granted medRxiv a license to display the preprint in perpetuity.

All rights reserved. No reuse allowed without permission.

\begin{tabular}{|c|c|c|}
\hline $\begin{array}{c}\text { Area under the } \\
\text { ROC curve }\end{array}$ & $73.90 \%$ & $74.26 \%$ \\
\hline Sensitivity & $53.33 \%$ & $59.11 \%$ \\
\hline Specificity & $79.76 \%$ & $76.97 \%$ \\
\hline $\begin{array}{c}\text { F-score } \\
\text { (harmonic mean } \\
\text { of Precision and }\end{array}$ & 0.45 & 0.34 \\
Recall) & & \\
\hline
\end{tabular}

ML logistic regression showed increased sensitivity (53.33\% vs. 14.46\%) and F score (0.45 vs.

0.23) compared to logistic regression. 
Figure 1. Correlation matrix for total PSB with demographic and clinical variables

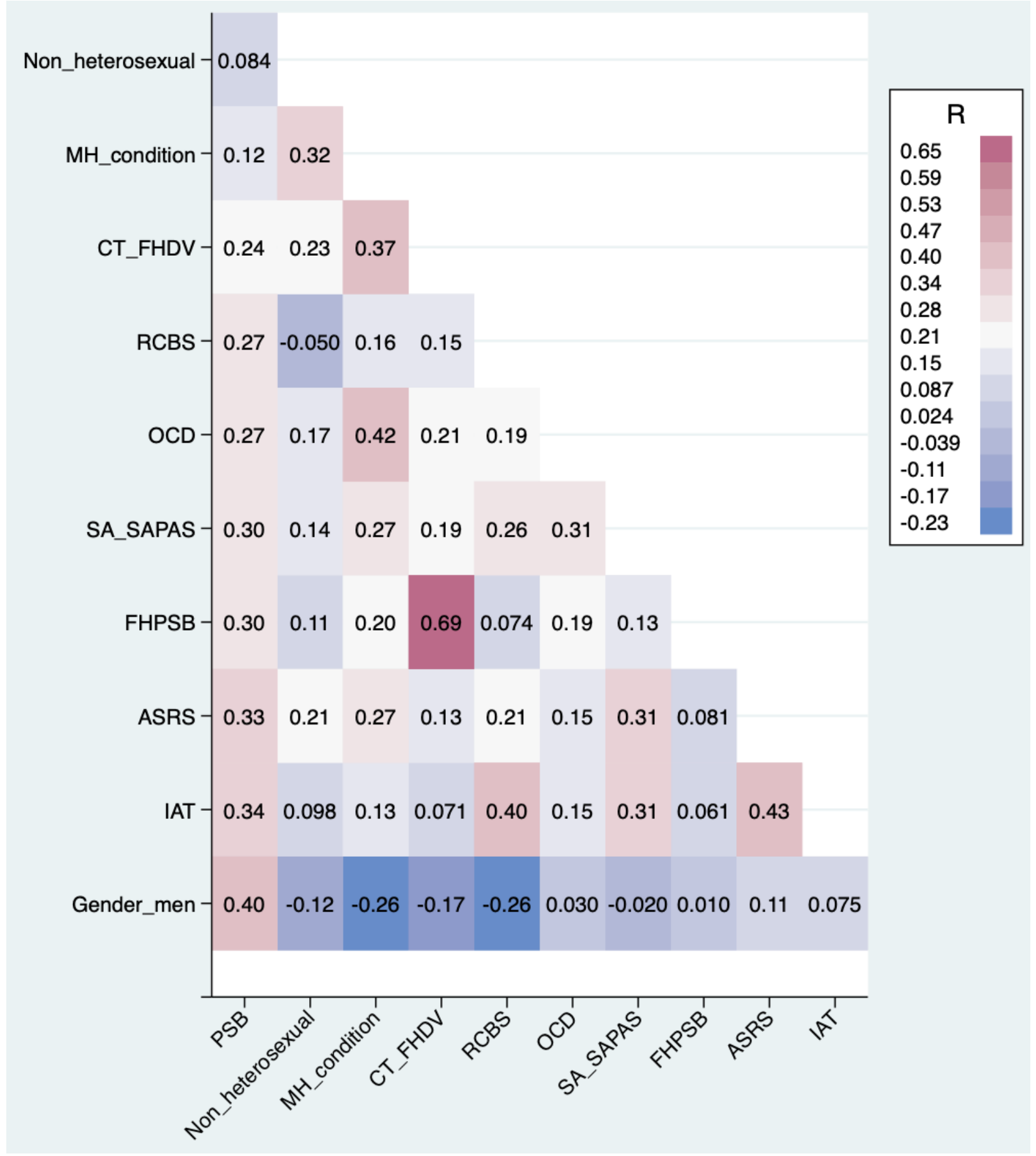

$P$ values are provided in Supplementary Table 3. 
medRxiv preprint doi: https://doi.org/10.1101/2022.01.31.21267382; this version posted February 10, 2022. The copyright holder for this preprint (which was not certified by peer review) is the author/funder, who has granted medRxiv a license to display the preprint in perpetuity.

All rights reserved. No reuse allowed without permission.

Figure 2. Forest plots of logistic regression of total PSB

A. By logistic regression (as in Table 2)

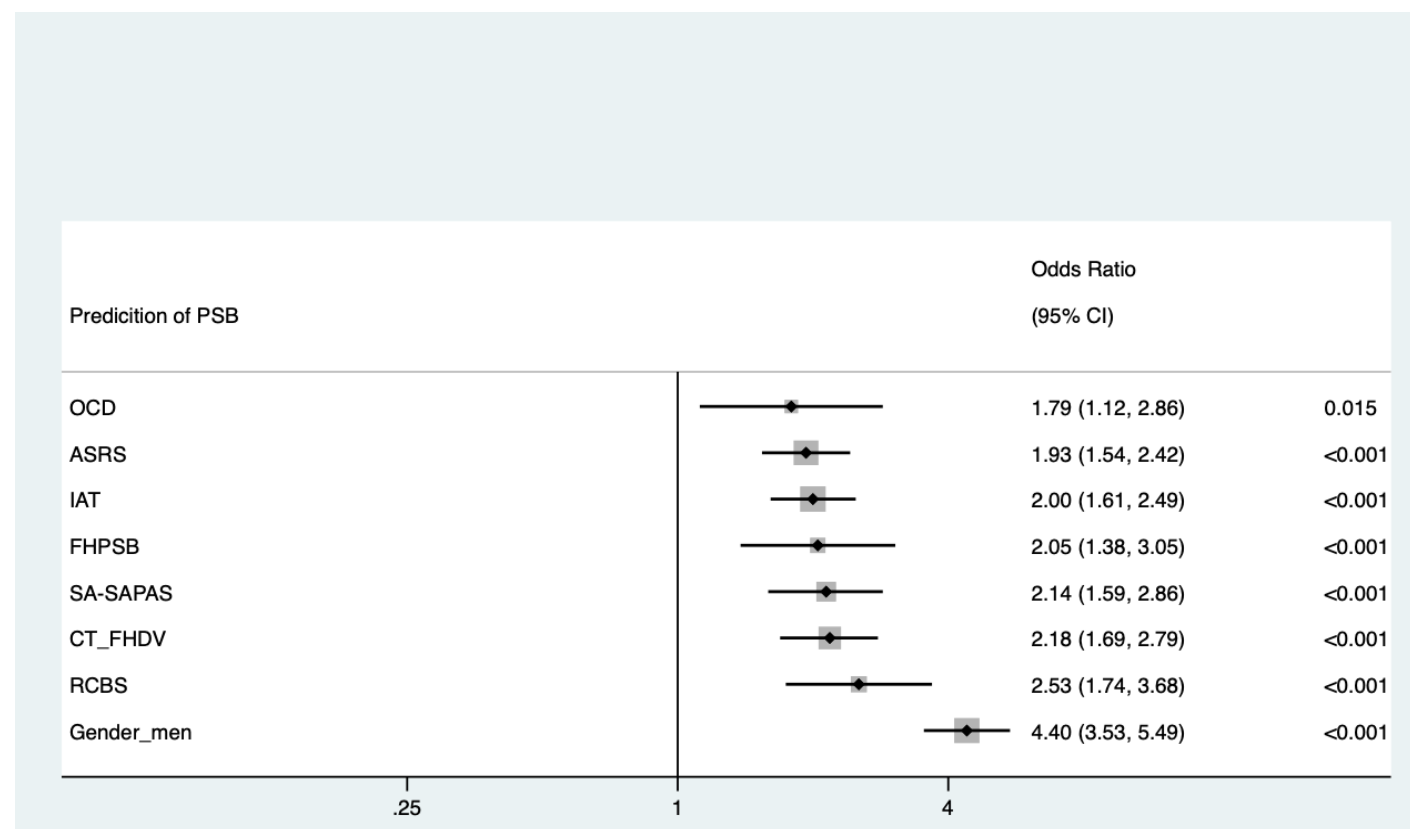


medRxiv preprint doi: https://doi.org/10.1101/2022.01.31.21267382; this version posted February 10, 2022. The copyright holder for this preprint (which was not certified by peer review) is the author/funder, who has granted medRxiv a license to display the preprint in perpetuity.

All rights reserved. No reuse allowed without permission.

\section{B. By machine learning (ML) logistic regression (Table 3, penultimate column)}

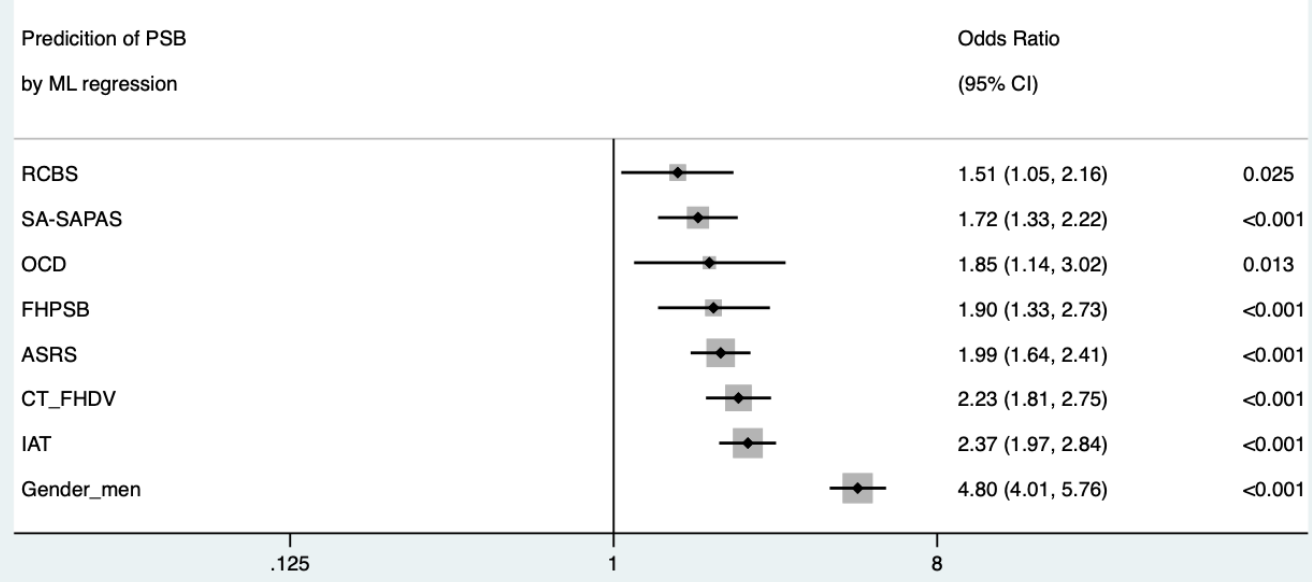


medRxiv preprint doi: https://doi.org/10.1101/2022.01.31.21267382; this version posted February 10, 2022. The copyright holder for this preprint (which was not certified by peer review) is the author/funder, who has granted medRxiv a license to display the preprint in perpetuity. All rights reserved. No reuse allowed without permission.

C. Validation of PSB predicting (training with SAST-R Core subtracting SASTC1 and SASTC2, testing with monthly PSB) by ML logistic regression (Table 3, last column)

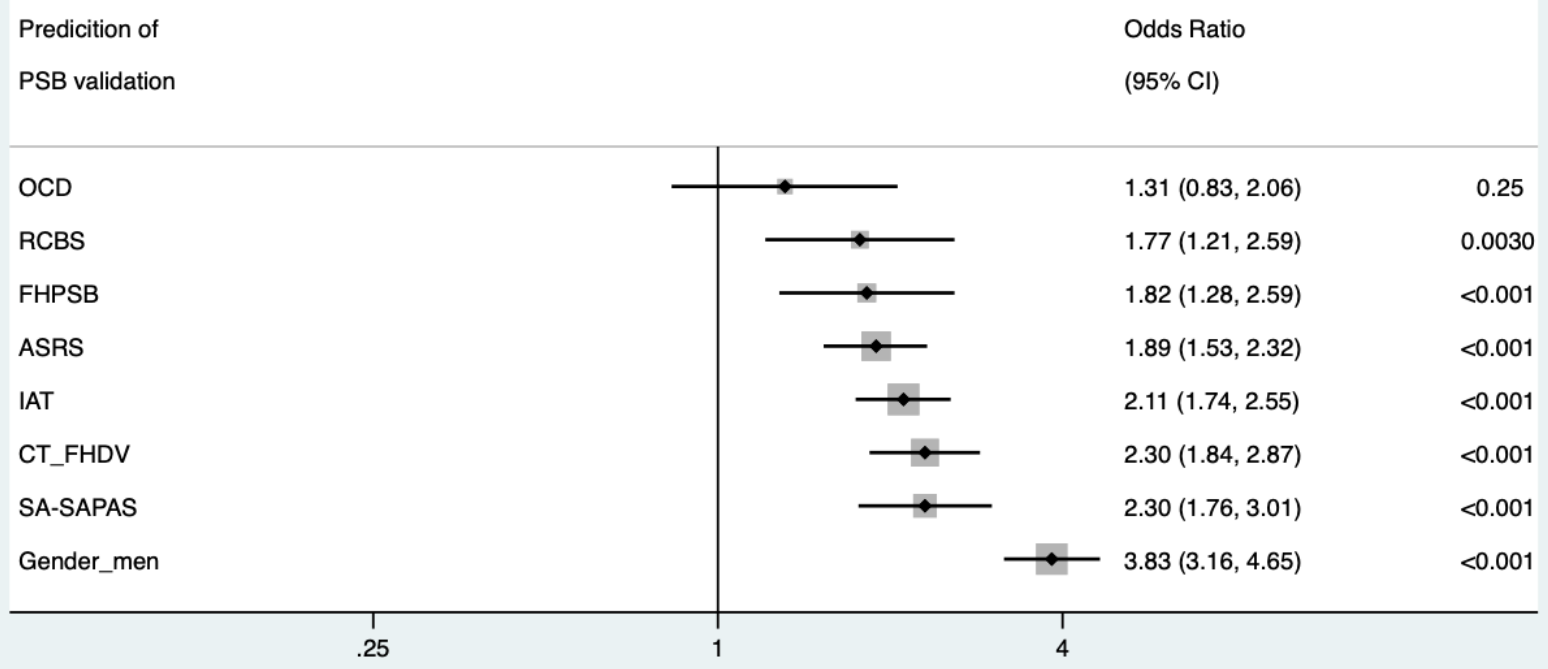


medRxiv preprint doi: https://doi.org/10.1101/2022.01.31.21267382; this version posted February 10, 2022. The copyright holder for this preprint (which was not certified by peer review) is the author/funder, who has granted medRxiv a license to display the preprint in perpetuity.

All rights reserved. No reuse allowed without permission.

Figure 3. Results of multiple correspondence analysis (dimensions 1 and 2) in women (A) and men (B)

\section{A. Results in women}

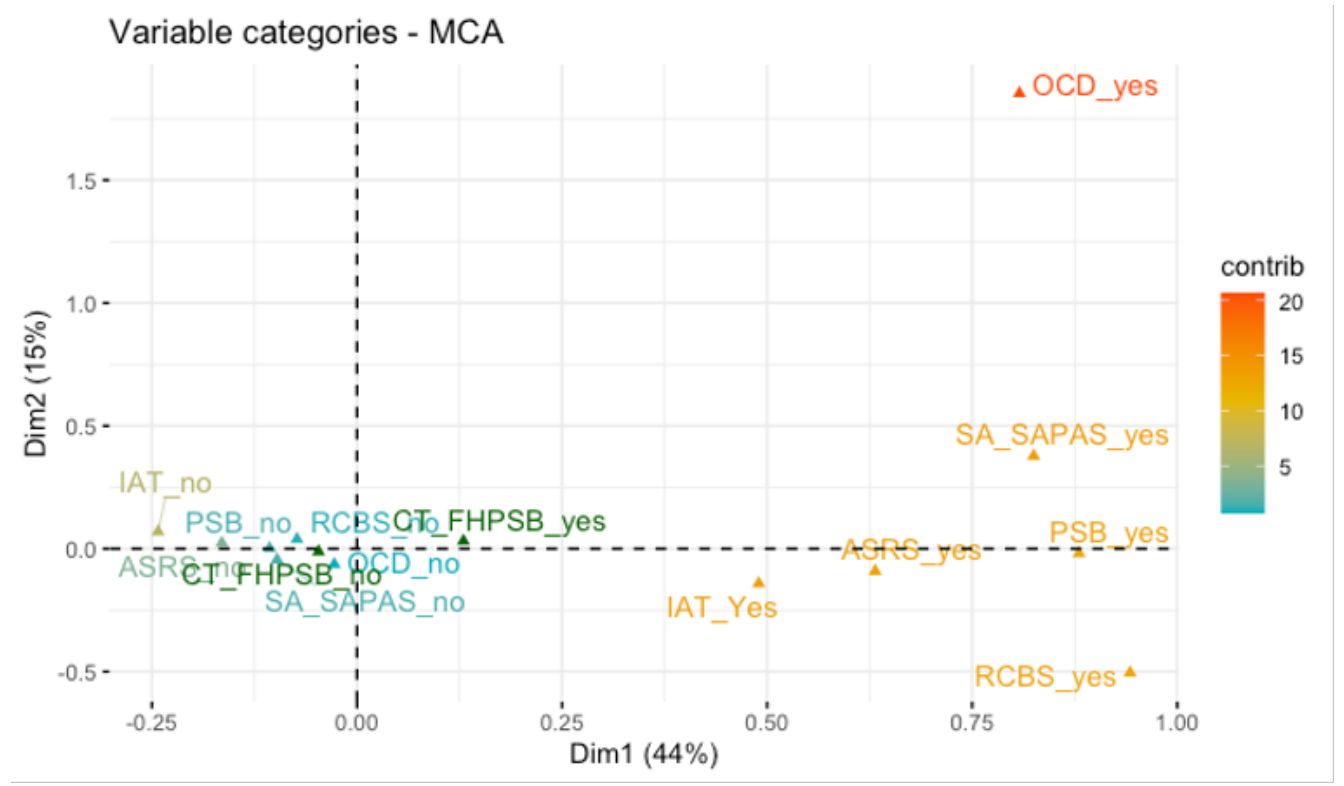

\section{B. Results in men}

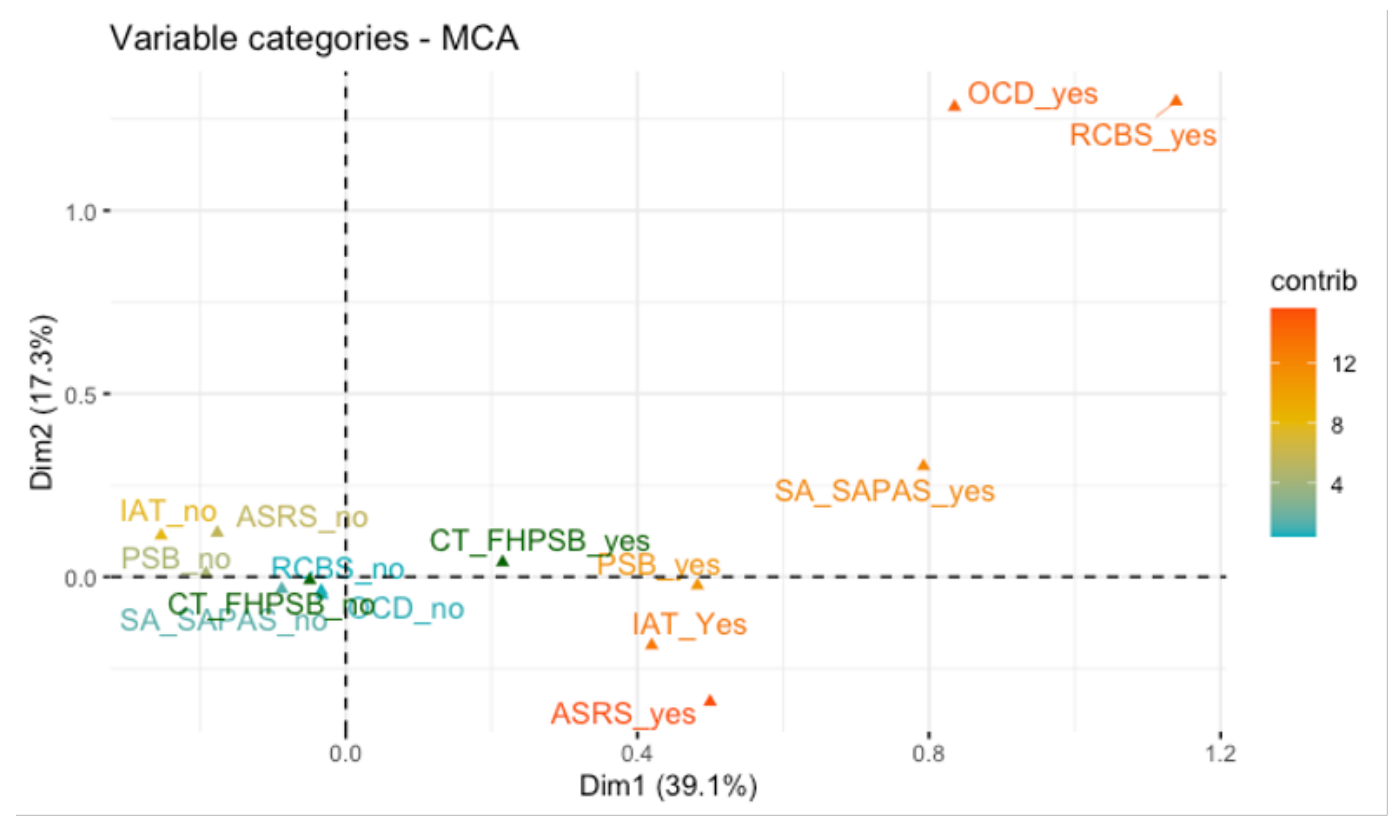


medRxiv preprint doi: https://doi.org/10.1101/2022.01.31.21267382; this version posted February 10, 2022. The copyright holder for this preprint (which was not certified by peer review) is the author/funder, who has granted medRxiv a license to display the preprint in perpetuity.

All rights reserved. No reuse allowed without permission.

Figure 4. Results of multiple correspondence analysis (dimensions 4 and 5) in women (A) and men (B)

\section{A. Results in women}

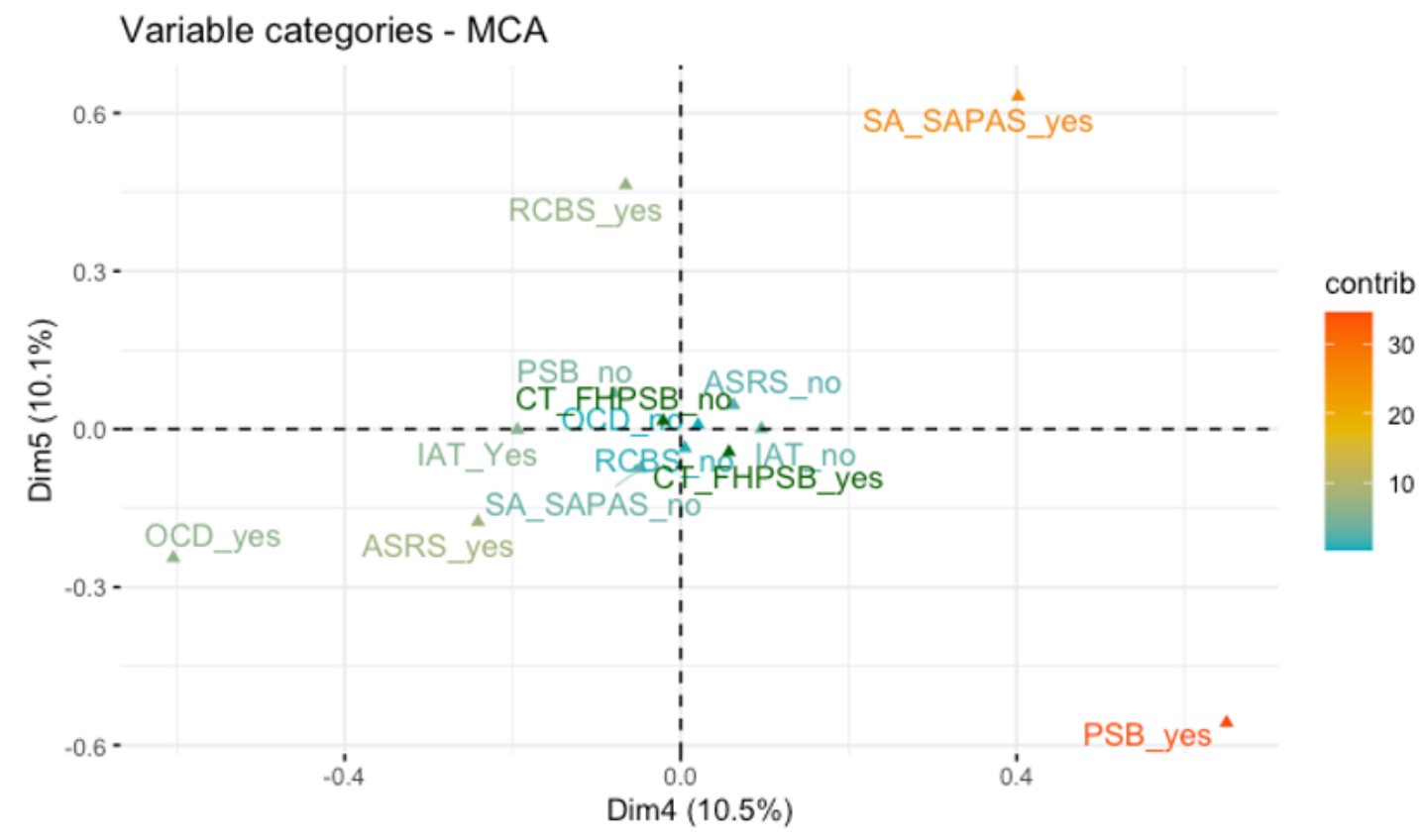

\section{B. Results in men}

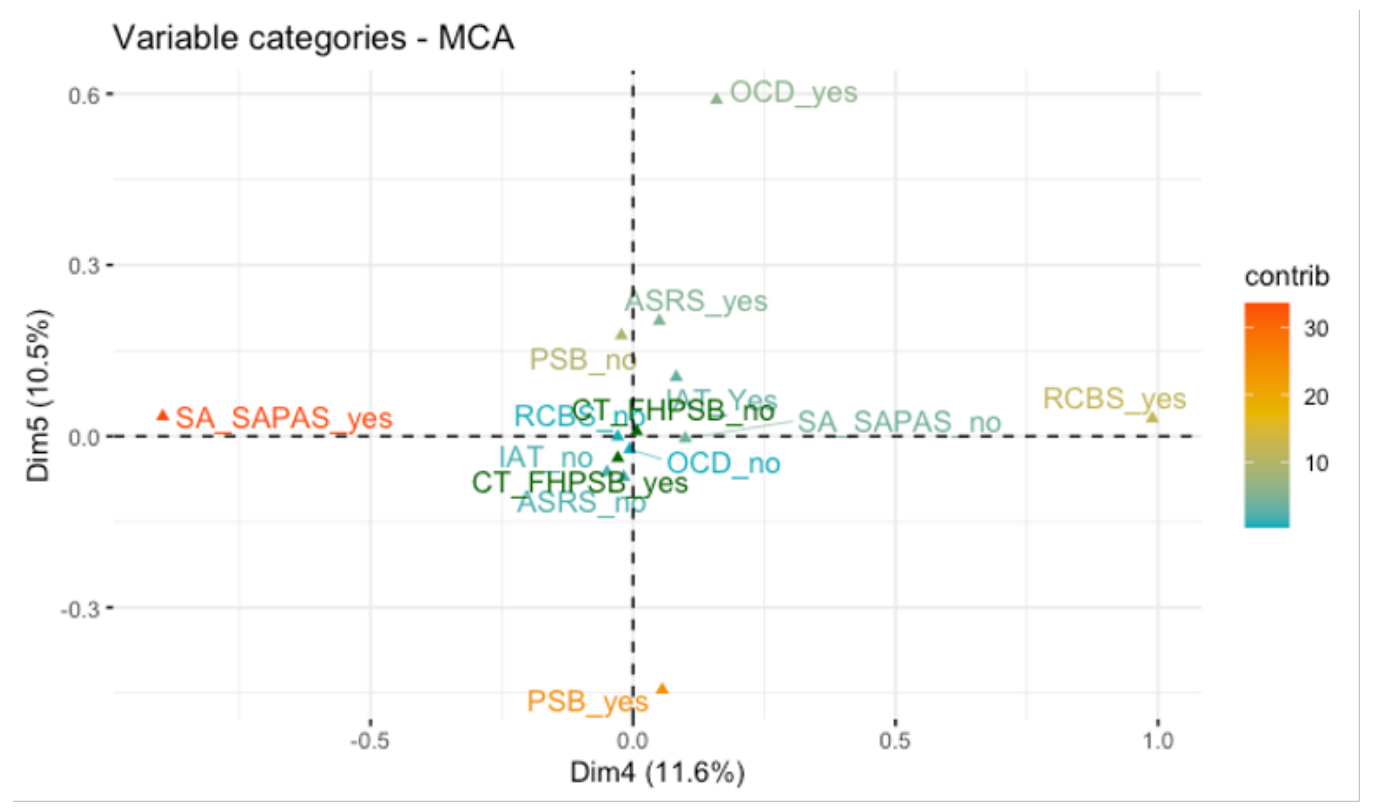




\section{References}

1. Orford J. Hypersexuality: implications for a theory of dependence. Br J Addict Alcohol Other Drugs. Sep 1978;73(3):299-10. doi:http://dx.doi.org/10.1111/j.1360-0443.1978.tb00157.x

2. Carnes P. Don't call it love : recovery from sexual addiction. Bantam Books; 1991:439 p.

3. Goodman A. Sexual addiction: terminology and theory. Psychiatric Times 1998;15(7):22-26.

4. Carnes P. Sexual addiction. 8 ed. vol I. Lippincott, Williams \& Wilkins: A Wolters Kluwer Company; 2005.

5. Carnes PJ, Hopkins TA, Green BA. Clinical relevance of the proposed sexual addiction diagnostic criteria: relation to the Sexual Addiction Screening Test-Revised. Journal of addiction medicine. Nov-Dec 2014;8(6):450-61. doi:http://dx.doi.org/10.1097/ADM.0000000000000080

6. Rosenthal RJ. Inclusion of pathological gambling in DSM-III, its classification as a disorder of impulse control, and the role of Robert Custer. International Gambling Studies. 2020;20(1):151-170. doi:https://doi.org/10.1080/14459795.2019.1638432

7. Rehm J, Probst C, Kraus L, Lev-Ran S. The addiction concept revisited. Reframing addiction: Policies, processes and pressures. The ALICE RAP project; 2014:103-117.

8. Kraus SW, Krueger RB, Briken P, et al. Compulsive sexual behaviour disorder in the ICD-11. World Psychiatry. Feb 2018;17(1):109-110. doi:10.1002/wps.20499

9. Griffiths MD. Compulsive sexual behaviour as a behavioural addiction: The impact of the internet and other issues. Addiction. 2016;111(12):2107-2108.

doi:http://dx.doi.org/10.1111/add.13315

10. Joannides P. The challenging landscape of problematic sexual behaviors, including "sexual addiction" and "hypersexuality.". New directions in sex therapy: Innovations and alternatives. 2012:69-83.

11. Dickenson JA, Gleason N, Coleman E, Miner MH. Prevalence of Distress Associated With Difficulty Controlling Sexual Urges, Feelings, and Behaviors in the United States. JAMA Netw Open. Nov 2 2018;1(7):e184468. doi:10.1001/jamanetworkopen.2018.4468

12. Carnes PJ, Green BA, Merlo LJ, Polles A, Carnes S, Gold MS. PATHOS: a brief screening application for assessing sexual addiction. J Addict Med. Mar 2012;6(1):29-34. doi:10.1097/ADM.0b013e3182251a28

13. Carnes PJ. Facing the Shadow: Starting Sexual and Relationship Recovery: a Gentle Path to Beginning Recovery from Sex Addiction. Gentle Path Press; 2015.

14. Klein V, Rettenberger M, Briken P. Self-reported indicators of hypersexuality and its correlates in a female online sample. J Sex Med. Aug 2014;11(8):1974-81.

doi:10.1111/jsm.12602

15. Reid RC, Li DS, Gilliland R, Stein JA, Fong T. Reliability, validity, and psychometric development of the pornography consumption inventory in a sample of hypersexual men. $J$ Sex Marital Ther. 2011;37(5):359-85. doi:10.1080/0092623x.2011.607047

16. Giordano AL, Cecil AL. Religious coping, spirituality, and hypersexual behavior among college students. Sexual Addiction \& Compulsivity. 2014;21(3):225-239.

doi:https://doi.org/10.1080/10720162.2014.936542

17. Cashwell C, L. Giordano A, Lewis T, A. Wachtel K, L. Bartley J. Using the PATHOS Questionnaire for Screening Sexual Addiction Among College Students: A Preliminary Exploration. vol 22. 2015. 
medRxiv preprint doi: https://doi.org/10.1101/2022.01.31.21267382; this version posted February 10, 2022. The copyright holder for this preprint (which was not certified by peer review) is the author/funder, who has granted medRxiv a license to display the preprint in perpetuity. All rights reserved. No reuse allowed without permission.

18. Deneke E, Knepper C, Green BA, Carnes PJ. Comparative study of three levels of care in a substance use disorder inpatient facility on risk for sexual addiction. Sexual Addiction \& Compulsivity. 2015;22(2):109-125.

19. Carnes PJ. The Sexual Addiction Screening Process. Clinical Management of Sex Addiction. 2019:21-39.

20. Blankenship R, Laaser M. Sexual Addiction and ADHD: Is There A Connection? Sexual Addiction \& Compulsivity. 2004/01/01 2004;11(1-2):7-20. doi:10.1080/10720160490458184

21. Ballester-Arnal R, Castro-Calvo J, Giménez-García C, Gil-Juliá B, Gil-Llario M. Psychiatric comorbidity in compulsive sexual behavior disorder (CSBD). Addictive behaviors. 2020;107:106384.

22. Grant JE, Lust K, Chamberlain SR. Body dysmorphic disorder and its relationship to sexuality, impulsivity, and addiction. Psychiatry Research. 2019/03/01/ 2019;273:260-265. doi:https://doi.org/10.1016/j.psychres.2019.01.036

23. London S, Quinn K, Scheidell JD, Frueh BC, Khan MR. Adverse Experiences in Childhood and Sexually Transmitted Infection Risk From Adolescence Into Adulthood. Sexually transmitted diseases. Sep 2017;44(9):524-532. doi:10.1097/OLQ.0000000000000640 24. Mick TM, Hollander E. Impulsive-compulsive sexual behavior. CNS Spectr. Dec 2006;11(12):944-55. doi:10.1017/s1092852900015133

25. Carnes $P$, Green B, Carnes $S$. The same yet different: Refocusing the Sexual Addiction Screening Test (SAST) to reflect orientation and gender. Sexual Addiction \& Compulsivity. 2010;17(1):7-30.

26. Young KS. Internet addiction: The emergence of a new clinical disorder. Cyberpsychology \& behavior. 1998;1(3):237-244.

27. Ridgway NM, Kukar-Kinney M, Monroe KB. An expanded conceptualization and a new measure of compulsive buying. Journal of consumer Research. 2008;35(4):622-639.

28. Merlhiot G, Mondillon L, Vermeulen N, Basu A, Mermillod M. Adaptation and Validation of the Standardized Assessment of Personality-Abbreviated Scale as a SelfAdministered Screening Test (SA-SAPAS). Journal of Psychology and Psychotherapy. 2014;4:6. doi:http://dx.doi.org/10.4172/2161-0487.1000164

29. Kessler RC, Adler L, Ames M, et al. The World Health Organization Adult ADHD SelfReport Scale (ASRS): a short screening scale for use in the general population. Psychol Med. Feb 2005;35(2):245-56. doi:10.1017/s0033291704002892

30. Heatherton TF, Kozlowski LT, Frecker RC, Fagerstrom KO. The Fagerström test for nicotine dependence: a revision of the Fagerstrom Tolerance Questionnaire. British journal of addiction. 1991;86(9):1119-1127.

31. Rennert L, Denis C, Peer K, Lynch KG, Gelernter J, Kranzler HR. DSM-5 gambling disorder: prevalence and characteristics in a substance use disorder sample. Experimental and clinical psychopharmacology. 2014;22(1):50-56. doi:10.1037/a0034518

32. Öncel SY, Gebizlioğlu ÖL, Alioğlu FA. Risk factors for smoking behavior among university students. Turkish Journal of Medical Sciences. 2011;41(6):1071-1080.

doi:http://dx.doi.org/10.3906/sag-1009-1122

33. Benedan L, Monti GS. Predicting the Risk of Gambling Activities in Adolescence: A Case Study. Springer; 2019:47-57.

34. Nwanganga F, Chapple M. Practical Machine Learning in R. John Wiley \& Sons; 2020. 35. Chen CY, Yang HCP, Chen CW, Chen TH. Diagnosing and revising logistic regression models: effect on internal solitary wave propagation. Engineering Computations. 2008; 
medRxiv preprint doi: https://doi.org/10.1101/2022.01.31.21267382; this version posted February 10, 2022. The copyright holder for this preprint (which was not certified by peer review) is the author/funder, who has granted medRxiv a license to display the preprint in perpetuity. All rights reserved. No reuse allowed without permission.

36. Hosmer Jr DW, Lemeshow S, Sturdivant RX. Applied logistic regression. vol 398. John Wiley \& Sons; 2013.

37. White IR, Daniel R, Royston P. Avoiding bias due to perfect prediction in multiple imputation of incomplete categorical variables. Comput Stat Data Anal. 2010;54(10):2267-2275. doi:10.1016/j.csda.2010.04.005

38. Momeni A, Pincus M, Libien J. Imputation and Missing Data. Introduction to Statistical Methods in Pathology. Springer International Publishing; 2018:185-200.

39. Shrestha N. Detecting Multicollinearity in Regression Analysis. American Journal of Applied Mathematics and Statistics. 2020/06/16 2020;8(2):39-42. doi:http://dx.doi.org/10.12691/ajams-8-2-1

40. $\quad$ Kim JH. Multicollinearity and misleading statistical results. Korean J Anesthesiol. Dec 2019;72(6):558-569. doi:10.4097/kja.19087 